\title{
PERBANDINGAN EFEKTIVITAS PEMBERIAN SUSU KEDELAI (Glycine $\max ($ L.) Merr) DENGAN REBUSAN AIR DAUN SIRSAK (Annona muricata Linn) DALAM MENURUNKAN KADAR ASAM URAT PADA WANITA MENOPAUSE
}

Filza Amalia Putri ${ }^{1}$

dr. Ilham Hariaji, M.Biomed ${ }^{2}$

${ }^{1}$ Mahasiswa Fakultas Kedokteran UMSU

${ }^{2}$ Departemen Farmakologi Fakultas Kedokteran UMSU

filza.ap@gmail.com

\begin{abstract}
ABSTRAK
Pendahuluan: Asam urat adalah produk akhir dari metabolisme protein dalam tubuh. Kadar asam urat normal $<6 \mathrm{mg} / \mathrm{dL}$ untuk wanita dan $<7 \mathrm{mg} / \mathrm{dL}$ untuk pria. Isoflavon termasuk flavonoid sering dimasukkan dalam tanaman seperti kedelai (Glycine max (L.) Merr dan daun sirsak (Annona muricata L.). Isoflavon bekerja untuk menghambat enzim xanthine oksidase. Metode: Penelitian analitik eksperimental menggunakan rancangan pretest satu kelompok. dan post test. Hasil : Dari hasil penelitian menggunakan uji Wilcoxon, diperoleh nilai susu kedelai p 0,001 dan menggunakan Paired T-Test, diperoleh nilai $\mathrm{p}$ daun sirsak $\mathrm{p}$ 0,0028 yang berarti ada pengaruh pemberian susu kedelai dan daun sirsak untuk mengurangi kadar asam urat pada wanita menopause.Setelah perbandingan antara keduanya, tidak ada perbedaan efektivitas antara susu kedelai dan sirsak air untuk mengurangi kadar asam urat pada wanita menopause $\mathrm{p}=0,105(\mathrm{p}<0,05)$. Ada pengaruh pemberian air susu kedelai dan daun sousop terhadap kadar asam urat dan tidak ada perbedaan efektivitas antara air susu kedelai dan daun sirsak untuk menurunkan kadar asam urat pada wanita menopause

Kata kunci: Menopause, Daun Sirsak, Susu Kedelai, Kadar Asam Urat
\end{abstract}

\begin{abstract}
Introduction: Uric acid is the end product of protein metabolism in the body. Uric acid levels are normally $<6 \mathrm{mg} / d L$ for women and $<7 \mathrm{mg} / \mathrm{dL}$ for men. Isoflavones including flavonoids are often included in plants such as soybeans (Glycine $\max ($ L.) Merr and soursop leaves (Annona muricata L.). Isoflavones work to inhibit the xanthine oxidase enzyme. Method: Analytical research experimental using the design of one group pretest and post test. Results From the study result using Wilcoxon test, it obtained the soy milk $p$ value is 0,001 and using Paired T-Test, it obtained the soursop leaves $p$ value is 0,0028 which means there is an effect by giving soy milk and soursop leaves to decrease uric acid level in menopausal women. After comparison between both of them, there is no difference in effectiveness between soymilk and soursop leaves water to decrease uric acid level in menopausal women $\mathrm{p}=0,105(\mathrm{p}<0,05)$. Conclusions: There is an effect of giving soy milk and sousop leaves water to uric acid levels and there is no difference in effectiveness between soymilk and soursop leaves water to decrease uric acid level in menopausal women at Pengajian Aisyiyah and Pengajian Komplek Kejaksaan Medan.
\end{abstract}

Keyword: Menopause, Soursop Leaves, Soy Milk, Uric Acid Level 


\section{PENDAHULUAN}

Asam urat adalah hasil akhir dari proses metabolisme purin di dalam tubuh. Asam urat tidak selamanya stabil di dalam darah. Kadar asam urat normal pada lakilaki di bawah $7 \mathrm{mg} / \mathrm{dL}$ sementara wanita di bawah $6 \mathrm{mg} / \mathrm{dL} .{ }^{1,2}$

Hiperurisemia adalah

keadaan dimana kadar kristal monosodium urat monohidrat di dalam darah berlebih. Kelebihan kadar asam urat tersebut bisa dikarenakan kelebihan produksi (over production) ataupun karena penurunan ekskresi asam urat melalui urin (under excretion) atau gabungan dari kedua penyebab diatas. $^{1,2,3}$

Survei epidemiologik yang dilakukan di Bandungan, Jawa Tengah atas kerjasama dengan WHO-COPCORD terhadap 4.683 sampel yang berusia antara 15-45 tahun didapatkan prevalensi hiperurisemia sebesar $24,3 \%$ pada laki-laki dan $11,7 \%$ pada wanita.

Pada laki-laki, kadar asam urat di dalam serum mulai tinggi selama pubertas. Namun sebaliknya pada wanita, kadar asam uratnya akan tetap rendah hingga menopause. Hal tersebut karena adanya efek urikosurik estrogen oleh enzim yang disebut urat oksidase atau urikase yang berfungsi mengoksidase purin menjadi alantoin. Apabila terjadi defisiensi urikase akan mengakibatkan tingginya kadar asam urat pada darah. ${ }^{4}$

Masyarakat Indonesia banyak menggunakan pengobatan secara herbal untuk menurunkan kadar asam urat di dalam darah. Masyarakat merasa pengobatan tradisional dari bahan alami yang lebih murah dan bahan bakunya lebih mudah didapatkan. Salah satunya adalah dengan mengkonsumsi rebusan daun sirsak (Annona muricata L.).

Daun dan buah sirsak memiliki kandungan seperti senyawa fruktosa, lemak, kalsium, protein, fosfor, besi, serta mengandung metabolit sekunder yaitu golongan tanin dan fitosferol. Selain itu daun sirsak juga mengandung senyawa monotetrahidrofuran asetogenin; seperti anomurisin A, annonasin-10one, dan lain-lain. ${ }^{5}$ Di dalam daun sirsak juga terdapat kandungan asetogenin yang bersifat antioksidan dan juga senyawa flavonoid. Flavonoid termasuk senyawa yang bersifat sebagai antioksidan dan mempunyai bioaktivitas sebagai obat. Sifat antioksidan yang terdapat pada daun sirsak tersebut menghambat produksi enzim xantin oksidase yang dapat mengurangi terbentuknya asam urat. ${ }^{7}$

Susu kedelai (Glycine max (L.) Merr juga memiliki kandungan $\mathrm{B} 1, \mathrm{~B} 2$, niasin, isoflavon, riboflavin, tiamin, karoten dan piridoksin. Kandungan isoflavon yang terdapat dalam susu kacang kedelai juga berperan dalam menghambat kerja dari xantin oksidase yang dapat menurunkan kadar asam urat. ${ }^{8,9}$

Berdasarkan data wanita Indonesia yang memasuki masa menopause semakin tahun semakin meningkat. Pada sensus penduduk tahun 2000 jumlah perempuan berusia diatas 50 tahun baru mencapai 15.5 juta jiwa atau 7,6\% dari total penduduk. Diperkirakan pada tahun 2020 jumlahnya akan 
meningkat menjadi 30,0 juta jiwa atau $11,5 \%$ dari total penduduk. ${ }^{10}$

Risiko seorang wanita mengalami hiperurisemia meningkat setelah masa menopause. Hal itu disebabkan karena pada wanita menopause sudah tidak ada hormon estrogen yang berperan membantu proses pembuangan asam urat dalam ginjal. Saat wanita mengalami menopause maka resiko terkena hiperurisemia akan menjadi sama dengan pria. ${ }^{11}$

Penelitian sebelumnya yang dilakukan oleh Ilkafah pada tahun 2017 menyatakan bahwa sebelum dilakukan pemberian rebusan daun sirsak nilai rata-rata asam urat responden adalah $11.3 \mathrm{mg} / \mathrm{dL}$ dan setelah pemberian rebusan daun sirsak nilai rata-rata asam urat menjadi $5,9 \mathrm{mg} / \mathrm{dL}^{5}$

Mark Messina dkk dalam penelitiannya menyatakan bahwa bahwa makanan berbahan dasar kedelai dapat membantu mengurangi risiko komorbiditas yang terkait dengan hiperurisemia dan asam urat. $^{13}$

\section{METODE}

Jenis penelitian ini adalah analitik eksperimental dengan rancangan One Group Pretest Posttest. Penelitian ini dilaksanakan di Klinik Aisyiyah Medan terletak di jalan Sisingamangaraja, Medan Amplas, Kota Medan dan di Komplek Kejaksaan di jalan Lizardi Putra, Medan Tuntungan. Penelitian dilakukan dengan 2 kali pengambilan darah perifer pada September 2018 dan Desember 2018.

Teknik pengambilan sampel adalah "Total sampling" dengan jumlah sampel sebanyak 60 orang terbagi menjadi 30 orang sampel susu kedelai dan 30 orang sampel air rebusan daun sirsak. Total sampling dipilih karena populasi kurang dari 100 orang, seluruh populasi dapat dijadikan sampel. Sampel yang diambil adalah ibu-ibu menopause dari pengajian Aisyiyah Ranting Melati Medan dan pengajian komplek Kejaksaan yang kemudian diberi penjelasan dahulu tentang tujuan penelitian, prosedur dari penelitian kemudian dilakukan anamnesis sesuai kriteria inklusi dan eksklusi, selanjutnya diberi surat informed consent yang ditanda tangani. Pemberian susu kedelai pada kelompok pertama selama 3 bulan dan air rebusan daun sirsak pada kelompok kedua selama 2 bulan.

Penelitian dilakukan dengan mengambil darah perifer dengan autocheck sebelum pemberian susu kedelai dan air rebusan daun sirsak. Kemudian pada kelompok pengajian Aisyiyah diberikan susu kedelai sebanyak $250 \mathrm{~mL}$ per hari selama 3 bulan dan pada kelompok pengajian Komplek Kejaksaan diberikan air rebusan daun sirsak sebanyak 2 gelas belimbing per hari selama 2 bulan. Setelah itu pada hari ke 91 untuk kelompok susu kedelai dan hari ke 61 untuk kelompok air rebusan daun sirsak dilakukan pengambilan darah perifer kembali dengan autocheck. ${ }^{5,12}$

\section{HASIL}

Kadar asam urat subjek penelitian sebelum dan sesudah pemberian susu kedelai dapat dilihat pada tabel berikut:

Tabel 4.1 Rata-rata susu kedelai

\begin{tabular}{lll}
\hline & $\begin{array}{l}\text { Rata-rata } \\
\text { pretest }\end{array}$ & $\begin{array}{l}\text { Std } \\
\text { deviasi }\end{array}$ \\
\hline Pretest & 5,98 & 1,602 \\
\hline
\end{tabular}




\begin{tabular}{lll}
\hline $\begin{array}{l}\text { Susu } \\
\text { kedelai }\end{array}$ & & \\
\hline $\begin{array}{l}\text { Posttest } \\
\text { Susu }\end{array}$ & 4,94 & 1,961 \\
kedelai & & \\
\hline $\begin{array}{l}\text { Selisih } \\
\text { Susu } \\
\text { kedelai }\end{array}$ & 1,04 & 2,336 \\
\hline
\end{tabular}

Dari tabel 4.1 didapatkan nilai rata-rata kadar asam urat sebelum perlakuan adalah 5,98 $\mathrm{mg} / \mathrm{dL}$ dan nilai rata-rata kadar asam urat setelah perlakuan adalah 4,94 $\mathrm{mg} / \mathrm{dL}$ dengan selisih antara keduanya adalah 1,04.

Kadar asam urat subjek penelitian sebelum dan sesudah pemberian air rebusan daun sirsak dapat dilihat pada grafik berikut:

Tabel 4.2 Rata-rata air rebusan daun sirsak

\begin{tabular}{lll}
\hline & $\begin{array}{l}\text { Rata-rata } \\
\text { pretest }\end{array}$ & $\begin{array}{l}\text { Std } \\
\text { deviasi }\end{array}$ \\
\hline $\begin{array}{l}\text { Pretest } \\
\text { daun } \\
\text { sirsak }\end{array}$ & 6,41 & 2,027 \\
\hline $\begin{array}{l}\text { Posttest } \\
\text { daun } \\
\text { sirsak }\end{array}$ & 6,05 & 1,565 \\
\hline $\begin{array}{l}\text { Selisih } \\
\text { daun } \\
\text { sirsak }\end{array}$ & 0,35 & 0,836 \\
\hline
\end{tabular}

Dari tabel 4.2 didapatkan nilai rata-rata kadar asam urat sebelum perlakuan adalah 6.41 $\mathrm{mg} / \mathrm{dL}$ dan nilai rata-rata kadar asam urat setelah perlakuan adalah 6.05 $\mathrm{mg} / \mathrm{dL}$ dengan selisih antara keduanya adalah 0,35.

\begin{tabular}{cccr}
\multirow{2}{*}{ kadar } & Setelah & \multicolumn{2}{c}{ didapatkan hasil } \\
asam & urat subjek p p \\
enelitian & dan r sesudah
\end{tabular}

perlakuan maka selanjutnya dilakukan uji normalitas data menggunakan Shaphiro-Wilk karena jumlah subjek 30. Didapatkan hasil dari uji normalitas data $\mathrm{p}<0,05$ yang menunjukkan data berdistribusi tidak normal.

Kemudian dilakukan analisis non parametrik Wilcoxon karena data berdistribusi tidak normal.

Tabel 4.3 Hasil Uji Wilcoxon Susu Kedelai

\begin{tabular}{ccccc}
\hline $\begin{array}{c}\text { Kelo } \\
\text { mpo }\end{array}$ & $\begin{array}{c}\text { Kada } \\
\mathbf{r}\end{array}$ & & $\begin{array}{c}\text { Seli } \\
\text { sih }\end{array}$ & $\begin{array}{c}\text { Nilai } \\
\mathbf{p}\end{array}$ \\
$\mathbf{k}$ & $\begin{array}{c}\text { Asam } \\
\text { Urat }\end{array}$ & & & \\
& & & \\
\hline $\begin{array}{c}\text { Susu } \\
\text { kede }\end{array}$ & $\begin{array}{c}\text { Pretes } \\
\text { lai }\end{array}$ & 5,9 & 1,0 & 0,001 \\
& Postte & 4,9 & 4 & \\
& st & 4 & & \\
\hline
\end{tabular}

Berdasarkan tabel 4.3 diatas terlihat bahwa kadar asam urat pada subjek penelitian yang didapatkan sebelum perlakuan adalah 5,98 dan setelah perlakuan 4,94 untuk susu kedelai dengan selisih diantaranya adalah 1,04. Nilai p pada kelompok susu kedelai adalah sebesar 0,001 $(p<0,05)$ yang berarti terdapat perbedaan bermakna pada kadar asam urat sebelum dan sesudah perlakuan.

Setelah didapatkan hasil kadar asam urat subjek penelitian sebelum dan sesudah perlakuan maka selanjutnya dilakukan uji normalitas data menggunakan Shaphiro-Wilk karena jumlah subjek 30. Didapatkan hasil dari uji normalitas data $p>0,05$ yang menunjukkan data berdistribusi normal. 
Kemudian dilakukan analisis parametrik T-test berpasangan karena data berdistribusi normal.

\begin{tabular}{|c|c|c|c|c|}
\hline \multirow{2}{*}{\multicolumn{2}{|c|}{$\begin{array}{l}\text { Tabel } \mathbf{4 . 4} \\
\text { Berpasangan } \\
\text { Sirsak }\end{array}$}} & Hasil & \multirow{2}{*}{$\begin{array}{l}\text { Uji } \\
\text { Rebusan }\end{array}$} & \multirow{2}{*}{$\begin{array}{l}\text { T-test } \\
\text { Daun }\end{array}$} \\
\hline & & Air & & \\
\hline $\begin{array}{l}\text { Kelo } \\
\text { mpok }\end{array}$ & $\begin{array}{l}\text { Kadar } \\
\text { Asam } \\
\text { Urat }\end{array}$ & & $\begin{array}{l}\text { Selis } \\
\text { ih }\end{array}$ & $\begin{array}{l}\text { Nilai } \\
\text { p }\end{array}$ \\
\hline Air & Pretes & 6,4 & 0,35 & 0,02 \\
\hline rebus & $t$ & 1 & & 8 \\
\hline an & Postte & 6,0 & & \\
\hline $\begin{array}{l}\text { daun } \\
\text { sirsa }\end{array}$ & $s t$ & 5 & & \\
\hline
\end{tabular}

Berdasarkan tabel 4.4 diatas terlihat bahwa kadar asam urat pada subjek penelitian yang didapatkan sebelum perlakuan adalah 6,41 dan setelah perlakuan 6,05 untuk susu kedelai dengan selisih diantaranya adalah 0,35 . Nilai p pada kelompok air rebusan daun sirsak adalah sebesar $0,028(p<0,05)$ yang berarti terdapat perbedaan bermakna pada kadar asam urat sebelum dan sesudah perlakuan.

Tabel 4.5 Nilai $\mathrm{p}$ dan selisih susu kedelai dan air rebusan daun sirsak

\begin{tabular}{lll}
\hline Kelompok & Nilai p & Selisih \\
\hline $\begin{array}{l}\text { Susu } \\
\text { kedelai }\end{array}$ & 0,001 & 1,04 \\
\hline Daun sirsak & 0,028 & 0,35 \\
\hline
\end{tabular}

Perbandingan efektivitas susu kedelai dan rebusan daun sirsak terhadap kadar asam urat dianalisis dengan menggunakan uji MannWhitney karena salah satu kelompok (susu kedelai) berdistribusi tidak normal. Dari hasil uji Mann-Whitney didapatkan nilai $\mathrm{p}=0,105 \quad(\mathrm{p}>0,05)$ yang berarti tidak ada perbedaan efektivitas antara susu kedelai dan air rebusan daun sirsak terhadap kadar asam urat pada wanita menopause.

\section{PEMBAHASAN}

Dari hasil penelitian mengenai perbandingan efektivitas pemberian susu kedelai dengan air rebusan daun sirsak terhadap kadar asam urat pada wanita menopause, didapati adanya efek susu kedelai dan air rebusan daun sirsak dalam menurunkan kadar asam urat pada wanita menopause. Hal ini sejalan dengan penelitian yang dilakukan oleh Gustiansyah pada tahun 2012 mendapatkan bahwa pemberian susu kacang kedelai pada tikus putih jantan dapat menurunkan kadar asam urat secara bermakna. ${ }^{8}$

Penelitian yang dilakukan Pui tahun 2008 menemukan bukti lebih lanjut peran estrogen dalam mengatur peningkatan ekskresi asam urat oleh ginjal melalui mekanisme meningkatkan renal clearance. Selain itu, dengan adanya estrogen maka URAT1 (Urate Transporter 1) yang merupakan transporter asam urat menjadi lebih rendah sehingga juga menurunkan reabsorbsi asam urat oleh ginjal. ${ }^{18}$

Sebuah penelitian yang dilakukan Villegas tahun 2012 juga menunjukkan hasil serupa bahwa produk olahan kedelai terkait dengan penurunan risiko hiperurisemia. ${ }^{14}$ Penelitian klinis lain oleh Liu Zhao Min tahun 2016 di China pada wanita menopause juga menunjukkan bahwa konsumsi kedelai jangka panjang tidak meningkatkan asam urat dalam darah, sehingga sumber makanan olahan kedelai tidak perlu dibatasi. ${ }^{15}$ 
Hasil ini diduga terkait kandungan isoflavon pada kedelai, yang memiliki sifat mirip estrogen yang berfungsi menekan pembentukan asam urat. ${ }^{16}$

Isoflavon tersebut termasuk golongan phytoestrogens yang dapat meningkatkan aktifitas positif dari estrogen dengan mengikat reseptor estrogen. ${ }^{19}$ Struktur kimia yang sama dengan estrogen membuat isoflavon pada kacang-kacangan memiliki sifat yang sama dengan estrogen untuk mengurangi resiko penyakit gout. ${ }^{13,19}$

Pada hasil air rebusan daun sirsak memiliki pengaruh terhadap kadar asam urat dengan nilai $\mathrm{p} 0,028$ $(\mathrm{p}<0,05)$ yang menunjukkan terdapat perbedaan bermakna terhadap hasil pemberian air rebusan daun sirsak, hal ini sejalan dengan penelitian yang dilakukan oleh Ilkafah di Makassar tahun 2017 yang mengatakan bahwa nilai rata-rata asam urat dari 32 responden sebelum dilakukan pemberian rebusan daun sirsak yaitu 11,3 mg/dL dan setelah pemberian rebusan daun sirsak yaitu $5,9 \mathrm{mg} / \mathrm{dLyang}$ menunjukkan ada penurunan kadar asam urat yang disebabkan sifat antioksidan yang dimiliki daun sirsak dan menghambat produksi enzim xanthine oxidase. ${ }^{5}$

Pemberian susu kedelai dan air rebusan daun sirsak dapat menurunkan kadar asam urat pada wanita menopause karena kandungan isoflavon yang dapat menghambat enzim xanthine oxidase dalam pembentukan asam urat. ${ }^{7,8,9}$

Dalam penelitian yang dilakukan oleh Hardoko tahun 2018, kandungan fitokimia yang terkandung di daun sirsak segar, daun sirsak kering dan teh herbal daun sirsak mengandung tannin, flavonoid dan steroid yang berperan dalam menghambat enzim xanthine oxidase. ${ }^{17}$

Dari hasil penelitian yang dilakukan tidak terdapat perbedaan efektvitas antara pemberian susu kedelai dan air rebusan daun sirsak dalam menurunkan kadar asam urat pada wanita menopause.

\section{KESIMPULAN}

Berdasarkan hasil penelitian dapat disimpulkan bahwa:

1. Pemberian susu kedelai $250 \mathrm{~mL}$ selama 3 bulan dapat menurunkan kadar asam urat pada wanita menopause

2. Pemberian air rebusan daun sirsak sebanyak 2 gelas belimbing per hari selama 2 bulan dapat menurunkan kadar asam urat pada wanita menopause

3. Tidak terdapat perbedaan efektivitas dari pemberian susu kedelai dan air rebusan daun sirsak terhadap kadar asam urat wanita menopause

\section{SARAN}

1. Penelitian ini dapat
dikembangkan
menambah faktor-faktor lain
seperti kelompok kontrol

2. Diharapkan kepada peneliti lainnya untuk lebih menambahkan sampel penelitian dikarenakan sampel pada penelitian ini masih terlalu sedikit. 


\section{DAFTAR PUSTAKA}

1. Mulalinda OC. Prevalensi Hiperurisemia pada Remaja Obese di SMA Kristen Tumou Kota Bitung. J e-Biomedik. 2014; 2(2): 426-430.

2. Mahajan A, Tabdon VR, Sharma S, Jandial C. Gout and menopause. JK Sci. 2007; 9(1): 50-51.

3. Lohr JW. Hyperuricemia: Background, Pathophysiology, Epidemiology. https://emedicine.medscape.com/ . Accessed June 25, 2018.

4. Harris MD, Siegel LB, Alloway JA. Gout and hyperuricemia. Artikel Review. Physician. 1999; 59(4): 925-934.

5. Ilkafah, Efektivitas Daun Sirsak dalam Menurunkan Nilai Asam Urat dan Keluhan Nyeri pada Penderita Gout di Kelurahan Tamalanrea Makassar. PHARMACON Jurnal Ilmiah Farmasi - UNSRAT. 2017; 6(2): 22-29.

6. Diana Sari I, Yuniar Y, Siahaan S, Syaripuddin M. Tradisi Masyarakat dalam Penanaman dan Pemanfaatan Tumbuhan Obat Lekat di Pekarangan Community Tradition in Planting and Using Medicinal Plant in Surround Home Yard. Jurnal Kefarmasian Indonesia. 2015; 5(2): 123-132.

7. Wijaya BR, Indriyanti A, Rahimah SB. Efek Pemberian Infusa Daun Sirsak (Annona Muricata Linn) Terhadap Penurunan Kadar Asam Urat dalam Darah pada Mencit Model Hiperurisemia. Prosiding Pendidikan Dokter 2014; (2460657X): 908-913.
8. Gustiansyah RJ. Efek Susu Kacang Kedelai ( Glycine max (L.) Merr.) terhadap Kadar Asam Urat Darah Tikus Putih Jantan yang Diinduksi Kalsium Oksonat. Skripsi UI. 2012: 24-39.

9. Wisudania, Riki V. Soybeans (Glycin max) Consumption to Delay Osteoporosis in Menopausal Women . literatur Study. Universitas Kristen Maranatha.

10. Rosyada, Mujahidah A, Fatimah SR. Faktor-Faktor yang Berhubungan dengan Usia Menopause. Jurnal Kesehatan Masyarakat. 2013; 4(m): 10-12.

11. Purba R B, Rumagit F, Loleh Novita P, Pola Makan Dan Kadar Asam Urat pada Wanita Menopause Yang Menderita Gout Arthritis di Puskesmas Tikala Barumanado. 2014.

12. Bau TR, Ida El,. Soymilk Processing with Higher Isoflavone Aglycone Content. 2015; 183: 161-168.

13. Messina M, Messina VL, Chan P. Soyfoods, Hyperuricemia and Gout: A Review of the Epidemiologic and Clinical Data. Asia Pacific Journal Clinical Nutrition. 2011; 20 (3): 347-358

14. Villegas R, Xiang Y, Elasy T, Xu W, Cai H, Cai Q et al. Purinerich foods, protein intake, and the prevalence of hyperuricemia: The Shanghai Men's Health Study. Nutr Metab Cardiovasc Dis. 2012; 22(5): 409-416.

15. Liu Z, Ho CS, Chen YM, Woo J. Can soy intake affect serum uric acid level? Pooled analysis from two 6-month randomized controlled trials among Chinese postmenopausal women with 
prediabetes or prehypertension. 2014; 54(1): 51-58.

16. Gaffo A, Saag K. Serum urate,menopause, and postmenopausal hormone use: from eminence to evidence-based medicine. Arthritis ResTher. 2008; 10(1478-6362): 120.

17. Hardoko, Tanudjaja Y, Mastuti TS, Halim Y. Utilization of Soursop Leaves as Antohyperuricemic in Functional Beverage "Herbal Green Tea".
International Food Research Journal. 2018; 25.

18. Pui K, Waddell C, Dalbeth N. Early Onset of Hyperuricaemia and Gout Following Treatment for Female to Male Gender Reassignment. Rheumatology. (Oxford). 2008;47(1840-1).

19. Gou K. Daidzen-metabolising phenotypes in relation to serum lipids and uric acids in Guangzhou, Cina. $\mathrm{Br} J$ Nutr. 2010. 